\title{
Kualitas Corporate Social Responsibility dan Penghindaran Pajak dengan Kinerja Laba Sebagai Moderator
}

\author{
Elisa Tjondro ${ }^{1 *}$, Retnaningtyas Widuri'1, Jacqueline Maria Katopo ${ }^{1}$ \\ Fakultas Ekonomi Universitas Kristen Petra Surabaya \\ Jl. Siwalankerto 121 -131, Surabaya 60228 \\ *Penulis korespondensi; E-mail: elisatjondro@petra.ac.id
}

\begin{abstract}
ABSTRAK
Tujuan penelitian ini adalah meneliti pengaruh kualitas corporate social responsibility (CSR) terhadap penghindaran pajak dengan kinerja laba sebagai variabel moderator. Penelitian ini menggunakan CSR award sebagai indikator kualitas corporate social responsibility (CSR). Data dianalisis menggunakan Moderated Regression Analysis. Sampel penelitian sebanyak 137 perusahaan yang terdaftar di Bursa Efek Indonesia dengan 615 pengamatan. Hasil penelitian membuktikan kualitas corporate social responsibility (CSR) berpengaruh negatif terhadap penghindaran pajak. Namun bila kualitas corporate social responsibility (CSR) dimoderasi dengan kinerja laba yang tinggi, maka menunjukkan pengaruh positif terhadap penghindaran pajak, artinya perusahaan dengan kualitas corporate social responsibility (CSR) yang baik cenderung mengalami peningkatan dalam penghindaran pajak saat kinerja laba tinggi.
\end{abstract}

Kata kunci: Kualitas corporate social responsibility, CSR award, penghindaran pajak, kinerja laba.

\begin{abstract}
The aim of this research is to investigate the impact of corporate social responsibility (CSR) quality on tax avoidance with earning performance as a moderator variable. This research uses CSR award as an indicator of corporate social responsibility quality. Data are analized using Moderated Regression Analysis (MRA). Sample is 137 listed companies in Indonesian Stock Exchange with 615 observations. Our result proves that CSR quality has a negative impact on tax avoidance. However, when corporate social responsibility quality is moderated by earning performance, the result shows a positive impact on tax avoidance. It means that when a company has a high profit, the better the quality of CSR will lead to higher tax avoidance.
\end{abstract}

Keywords: Corporate social responsibility quality, CSR award, tax avoidance, earnings performance.

\section{PENDAHULUAN}

Friedman (1970) menyatakan tanggung jawab sosial tidak akan terjadi jika tidak ada pemahaman yang sama (kebulatan suara) antara perusahaan, pemerintah, dan masyarakat. Tanggung jawab sosial tidak akan terjadi bila tidak ada perikatan secara sukarela di dalamnya. Tidak adanya kerelaan dalam aktivitas CSR ini akan menimbulkan mekanisme politik, berupa penghindaran pajak, yang tidak dapat dihindarkan. Menurut Carroll (1979), konsep awal CSR terdiri dari empat unsur yaitu: (1) Economic responsibility, dimana perusahaan bertanggung jawab untuk menjual barang dan jasa yang diinginkan masyarakat dengan memperoleh profit; (2) Legal responsibility, dimana masyarakat berharap perusahaan memenuhi economic responsibility dalam ruang lingkup hukum dan regulasi yang berlaku di tempat perusahaan beroperasi; (3) Ethical responsibility, dimana masyarakat mengharapkan perusahaan melakukan perilaku dan aktivitas yang dikategorikan etis; (4) Voluntary responsibility, dimana perusahaan berpartisipasi dalam kegiatan sosial, yang tidak diwajibkan oleh hukum, aturan, atau tidak terkait dengan tindakan etis/non-etis. Ini berarti pada awalnya CSR ditopang oleh keempat unsur tersebut, sehingga 
dapat berjalan sebagaimana seharusnya. Ditetapkannya CSR ke dalam Undang-Undang No 40 Tahun 2007 yang menjadi salah satu kewajiban perusahaan, menyebabkan konsep dasar CSR yang seharusnya terdiri dari empat unsur, menjadi hanya dua unsur (economic responsibility dan legal responsibility). Unsur ethical dan voluntary responsibility menjadi hilang karena CSR tidak lagi dipandang sebagai tindakan beretika dan bersifat sukarela, namun lebih kepada kewajiban yang harus dipenuhi agar perusahaan dapat terus beroperasi di Indonesia. Perusahaan dibangun dengan konsep dasar economic responsibility, artinya manajemen sebagai karyawan, bertanggung jawab kepada pemegang saham untuk mendapatkan keuntungan yang sebesar-besarnya, tetapi harus sejalan dengan hukum dan aturan yang berlaku (legal responsibility). Demi memenuhi kedua tanggung jawab tersebut, manajemen akan melakukan berbagai cara untuk memenuhi tuntutan keduanya dengan sumber daya terbatas yang dimilikinya, termasuk melakukan penghindaran pajak. Inilah sudut pandang pertama dari CSR. Beberapa penelitian mendukung pandangan ini, seperti: Friedman (1970) menyebutkan bahwa perusahaan hanya melakukan aktivitas CSR jika memaksimalkan keuntungannya; Davis et al (2013) menyebutkan bahwa sebagian besar manajer dan stakeholder lainnya tidak melihat pajak sebagai salah satu bagian penting dari tanggung jawab sosial perusahaan terhadap masyarakat.

Di Indonesia praktek CSR belum diperkuat dengan aturan dan penilaian yang jelas. Belum ada aktivitas CSR yang dapat diukur secara operasional (Suharto, 2008). Menurut Suharto (2008), Undang- Undang CSR di Indonesia belum diikuti peraturan yang lebih detail. Standar untuk mengevaluasi CSR juga masih menjadi perdebatan. Akibatnya banyak perusahaan di Indonesia yang menjalankan CSR hanya sekedar menghabiskan anggaran atau menjalankan kegiatan yang sama setiap tahun. Program CSR dilakukan tidak melihat pada kebutuhan masyarakat. Akibatnya banyak program CSR yang tumpang tindih, kegiatan yang sama di wilayah yang sama, serta kegiatan sama yang dilakukan berulangulang selama beberapa tahun (Suharto, 2008).

Sudut pandang kedua melihat bahwa pembayaran pajak merupakan bagian dari aktivitas CSR. Menurut Hoi, Wu dan Zhang (2013) menyebutkan pembayaran pajak adalah salah satu cara mendasar bagi perusahaan untuk terlibat dengan masyarakat. Hal ini berarti perusahaan dengan kualitas CSR yang baik, juga akan menghindari praktik penghindaran pajak, karena pajak merupakan bagian dari aktivitas CSR. Perusahaan yang berkomitmen melakukan aktivitas CSR secara berkelanjutan, juga melakukan pembayaran pajak secara bertanggung jawab. Dalam penelitian Hoi, Wu dan Zhang (2013) menyebutnya sebagai responsible CSR. Hoi, Wu, \& Zhang (2013) mengklasifikasikan aktivitas CSR menjadi dua, yaitu: responsible CSR dan irresponsible CSR. Hasil penelitiannya menemukan bahwa perusahaan yang banyak melakukan responsible CSR lebih tidak agresif dalam penghindaran pajak dibanding perusahaan yang melakukan irresponsible CSR. Lanis dan Richardson (2015) juga menemukan semakin tinggi kualitas CSR perusahaan, semakin rendah kemungkinan penghindaran pajak oleh perusahaan. Christensen dan Murphy (2004) mengemukakan bahwa perusahaan yang bertanggung jawab sosial membayar pajak dalam jumlah yang wajar.

Penelitian terdahulu mengenai kualitas CSR di Indonesia menggunakan content analysis dengan indikator jumlah poin pengungkapan (menurut Global Reporting Initiative (GRI) Index) yang tercantum dalam sustainability report perusahaan. Metode tersebut memiliki banyak kelemahan, yaitu: (1) banyaknya jumlah pengungkapan dalam sustainability report tidak mejelaskan perusahaan memiliki kualitas CSR yang lebih baik. Mungkin saja terjadi informasi yang diungkapkan lebih kecil daripada kegiatan CSR yang dilakukan. Namun bisa saja terjadi pengungkapan yang dilakukan melebihi aktivitas CSR yang nyata; (2) subjektivitas dalam proses scoring. (Gunawan, 2009). Penelitian Hoi, Wu dan Zhang (2013) menggunakan hasil audit aktivitas perusahaan atas tujuh komponen untuk membedakan irresponsible us responsible CSR, yaitu: corporate governance, employee relation, environment, community, diversity, human right, product quality and safety. Di Indonesia belum ada hasil audit kualitas CSR yang dipublikasikan secara umum, tetapi banyak perusahaan Indonesia yang menerima CSR award, baik berupa penghargaan dalam negeri, maupun penghargaan internasional, antara lain Global CSR Summit and Award yang diadakan oleh Pinnacle Group International dan Indonesia CSR Award yang diadakan oleh lembaga non-profit Corporate Forum for Community Development (CFCD). Penelitian ini menggunakan CSR award sebagai indikator kualitas CSR yang diberikan oleh kedua lembaga tersebut.

Pengaruh kualitas CSR terhadap penghindaran pajak semakin menarik diteliti karena Watson (2014) menemukan bahwa semakin tinggi kualitas CSR perusahaan, semakin tinggi penghindaran pajak yang dilakukan perusahaan, dalam kondisi kinerja laba yang rendah. Namun pengaruh keduanya tidak terjadi dalam kondisi 
kinerja laba tinggi. Artinya perusahaan dengan kualitas CSR yang baik tidak melakukan penghindaran pajak, bila kinerja laba pada tahun tersebut tinggi dan sumber daya yang dimiliki perusahaan mencukupi. Namun bila kinerja mengalami penurunan, maka manajemen perlu melakukan alokasi antara CSR dan pajak, sehingga timbullah penghindaran pajak yang dilakukan perusahaan (teori slack resource).

Adapun tujuan dari penelitian ini untuk menguji dan memberikan bukti empiris mengenai pengaruh kualitas CSR terhadap penghindaran pajak dengan kinerja laba sebagai moderator. Tujuan pertama adalah mengetahui apakah kualitas CSR diikuti juga dengan perilaku penghindaran pajak yang rendah oleh perusahaan. Alasannya (1) kualitas CSR yang baik didominasi perusahaan yang melakukan CSR secara sukarela, bukan karena kewajiban (mengingat tidak semua perusahaan di Indonesia wajib CSR); (2) kualitas CSR yang baik didominasi perusahaan yang memiliki sumber daya berlimpah, sehingga tidak terjadi tarik ulur dalam alokasi CSR dan pajak; (3) Kualitas CSR yang baik didominasi perusahaan dengan kinerja laba yang tinggi, sehingga pembayaran pajak menjadi lebih tinggi. Tujuan kedua mengetahui apakah kinerja laba yang tinggi memperkuat pengaruh kualitas CSR terhadap penghindaran pajak.

Kontribusi penelitian ini adalah penelitian ini yang pertama kali menggunakan CSR award sebagai indikator kualitas CSR, sedangkan penelitian-penelitian sebelumnya masih menggunakan jumlah pengungkapan dalam sustainability report. Penggunaan CSR award dirasa lebih tepat sebagai indikator kualitas CSR dibanding indikator lainnya karena penilaian CSR award menilai aktivitas CSR berdasarkan kinerja nyata yang dilakukan, bukan pada analisis laporan sustainability. Adapun penilaian CSR award didasarkan pada: (1) sesuai dengan kebutuhan masyarakat (original), (2) berkelanjutan (sustainable), (3) inovatif, dan (4) berdampak bagi masyarakat (high impact). Kontribusi kedua adalah penelitian ini yang pertama meneliti (dalam konteks Indonesia) kinerja laba sebagai variable moderator yang memperkuat pengaruh kualitas CSR terhadap penghindaran pajak.

\section{Teori Slack Resources dan Penghindaran Pajak}

Hubungan kualitas CSR dan penghindaran pajak dapat dijelaskan dengan Teori Slack Resources. Perusahaan dengan kualitas CSR yang baik memberikan sinyal bahwa perusahaan tersebut kaya (Lys, Naughton, dan Wang 2013). Perusahaan yang kaya memiliki cukup banyak sumber daya sehingga mereka dapat memenuhi kewajiban terkait CSR dan pembayaran pajak dengan mudah. Ini didukung penelitian Campbell (2007) menyatakan pada saat kinerja laba perusahaan tinggi, maka perusahaan dapat mengalokasikan sumber daya dalam bentuk program CSR yang lebih baik atau pembayaran pajak yang lebih tinggi. Mereka juga dapat melakukan aktivitas CSR secara berkelanjutan dan terencana tanpa terkendala keuangan. Di sisi lain mereka tetap dapat memenuhi kewajiban dalam membayar pajak sesuai aturan yang berlaku. Bagaimana saat kinerja perusahaan mengalami penurunan? Camphell (2007) menyebutkan bila sumber daya sangat terbatas, perusahaan akan mengalokasikan jumlah yang terbatas bagi CSR dan pajak.

Banyak pemahaman terkait pengertian penghindaran pajak. Hanlon dan Heitzman (2010) dalam Cheng, et al. (2012) mendefinisikan penghindaran pajak sebagai kegiatan yang mengurangi pajak eksplisit terhadap laba akuntansi sebelum pajak. Aktivitas penghindaran pajak yang dilakukan oleh manajemen suatu perusahaan dalam upaya meminimalisasi kewajiban pajak perusahaan (Khurana \& Moser, 2009). Penghindaran pajak adalah bagian dari perencanaan pajak perusahaan dalam bentuk pengurangan pajak yang dilakukan secara eksplisit dengan cara apapun. Lietz (2013) membagi strategi perencanaan pajak perusahaan menjadi perfectly legal, grey area, and clearly illegal. Penghindaran pajak dalam penelitian ini adalah segala upaya pengurangan pajak, baik secara legal maupun ilegal. Mengapa secara legal maupun ilegal? Karena segala bentuk penghindaran pajak merupakan suatu hal yang tidak beretika dan tidak bertanggung jawab sosial, atau dengan kata lain tidak memenuhi konsep ethical responsibility, yang mana merupakan salah satu pilar dalam konsep CSR (Carrol, 1979). Pengertian ini konsisten dengan penelitian Dyreng, Hanlon, \& Maydew, (2010) yang menyatakan bahwa penghindaran pajak tidak membedakan apakah dilakukan secara legal, tidak legal, ataupun grey area. Hoi, Wu dan Zhang (2013) menyebutkan bahwa pembayaran pajak adalah salah satu cara mendasar bagi perusahaan untuk terlibat dengan masyarakat. Christensen dan Murphy (2004), Davis et al., (2013) menyebutkan bahwa perusahaan yang bertanggung jawab sosial membayar pajak dalam jumlah yang wajar sehingga tingkat penghindaran pajak yang tinggi akan menyebabkan suatu perusahaan menjadi tidak bertanggung jawab sosial. Menurut Lietz (2013), terdapat beberapa indikator yang digunakan untuk mengukur penghindaran pajak. Namun indikator yang paling sering digunakan dalam penelitian adalah Cash Effective Tax Rate (CETR). 


\section{Kualitas Corporate Social Responsibility (CSR)}

Menurut World Business Council for Sustainable Development (WBCSD), pengertian CSR adalah komitmen bisnis untuk memberikan kontribusi bagi pembangunan ekonomi berkelanjutan dengan bekerja sama antara perusahaan, karyawan, komunitas setempat maupun masyarakat, guna meningkatkan kualitas kehidupan yang nantinya memberikan manfaat bagi perusahaan sendiri maupun untuk pembangunan. CSR adalah suatu cara atau strategi perikatan dengan komunitas masyarakat, yang memiliki manfaat jangka panjang bagi perusahaan, tidak hanya dimotivasi oleh laba, tetapi berjalan bersamaan dengan kesejahteraan sosial maupun perlindungan terhadap lingkungan (Koestoer, 2014). Pengertian CSR menurut Undang-Undang Nomor 40 Tahun 2007 tentang Perseroan Terbatas pasal 1 ayat 3 menyebutkan bahwa Tanggung Jawab Sosial dan Lingkungan adalah komitmen Perseroan untuk berperan serta dalam pembangunan ekonomi berkelanjutan guna meningkatkan kualitas kehidupan dan lingkungan yang bermanfaat, baik bagi Perseroan sendiri, komunitas setempat, maupun masyarakat pada umumnya. Beberapa pengertian tersebut memberi kesimpulan bahwa perusahaan dikatakan melakukan aktivitas CSR, bila (1) dilakukan secara berkelanjutan, (2) dampaknya adalah meningkatkan kualitas kehidupan dan lingkungan perusahaan, komunitas, maupun masyarakat.

Bagaimana ukuran kualitas CSR yang mendatangkan kesejahteraan sosial bagi masyarakat? Berdasarkan kriteria penilaian Global CSR Summit and Award, perusahaan dikatakan memiliki kualitas CSR yang bagus bila memenuhi empat kriteria: (1) sesuai dengan kebutuhan masyarakat (original), (2) berkelanjutan (sustainable), (3) inovatif, dan (4) berdampak bagi masyarakat (high impact). Di USA telah ada lembaga independen pemeringkat kualitas CSR yaitu KLD. Pada tahun 2003 KLD telah memberikan penilaian untuk 3000 perusahaan go publik di USA. Berdasarkan database KLD, penelitian Watson (2014) membedakan kualitas CSR menjadi dua, responsible CSR dan irresponsible CSR. Di Indonesia belum ada lembaga independen seperti KLD yang mempublikasikan hasil penilaiannya dalam database. Namun telah banyak lembaga pemeringkat aktivitas CSR, baik organisasi international maupun nasional, yaitu: Pinnacle Group International dan Corporate Forum for Community Development (CFCD). Penelitian ini menggunakan CSR award sebagai dasar untuk menilai efektivitas aktivitas CSR yang dilakukan perusahaan, sehingga dalam penelitian ini perusahaan akan dibagi menjadi 2 , yang menerima CSR award dan yang tidak menerima CSR award (menggunakan variable dummy, $1=$ menerima award, $0=$ tidak menerima award).

\section{Pengaruh Kualitas CSR terhadap Penghin- daran pajak}

Bila dikaitkan dengan penghindaran pajak, perusahaan dengan kualitas CSR yang baik, akan melakukan kegiatan CSR yang berkelanjutan dan membayar pajak yang sewajarnya. Sebaliknya perusahaan dengan kualitas CSR yang buruk akan melakukan alokasi antara pengeluaran untuk aktivitas CSR dan pembayaran pajak. Ini terjadi karena terbatasnya sumber daya yang ada. Praktik penghindaran pajak yang dilakukan adalah dengan membebankan biaya CSR sebagai pengurang penghasilan bruto, sehingga laba menjadi lebih kecil, dan pada akhirnya pembayaran pajak yang lebih rendah. Dengan tarif pajak penghasilan perusahaan publik di Indonesia adalah $25 \%$ dari laba bersih, maka biaya CSR dapat menghemat pembayaran pajak hingga $25 \%$. Biaya CSR diatur dalam Undang Undang No 36 Tahun 2008 pasal 6 menyatakan biaya CSR yang dilakukan di Indonesia dapat dikurangkan dari penghasilan bruto, dalam menghitung pajak penghasilan perusahaan. Biaya CSR yang dapat dikurangkan dari penghasilan bruto adalah (1) sumbangan dalam rangka penanggulangan bencana nasional, (2) sumbangan dalam rangka penelitian dan pengembangan, (3) pembangunan infrastruktur sosial, (4) sumbangan fasilitas pendidikan, (5) sumbangan dalam rangka pembinaan olahraga. Dengan adanya aturan tersebut, perusahaan dengan kualitas CSR yang buruk dapat melakukan penghindaran pajak dengan memperbesar biaya CSR yang tidak direncanakan supaya biaya yang dapat dikurangkan dari penghasilan bruto menjadi lebih besar dan pada akhirnya pembayaran pajak yang lebih rendah. Namun praktik ini tidak terjadi pada perusahaan dengan kualitas CSR yang baik. Penelitian ini memprediksi perusahaan dengan kualitas CSR yang baik akan melakukan pembayaran pajak yang lebih besar karena mereka memiliki sumber daya yang berlimpah, sehingga tidak perlu melakukan alokasi antara CSR dan pajak. Berdasarkan penjelasan di atas, maka hipotesis penelitian adalah:

$\mathrm{H}_{1}$ : Kualitas CSR berpengaruh negatif terhadap penghindaran pajak.

\section{Pengaruh CSR terhadap Penghindaran Pajak dengan Kinerja Laba sebagai Moderator}

Perusahaan dengan kualitas CSR yang baik dan kinerja laba yang tinggi, semakin kecil 
kemungkinan melakukan penghindaran pajak, dikarenakan memiliki sumber daya yang melimpah dan perusahaan lebih mampu melakukan aktivitas CSR dan pembayaran pajak secara bertanggung jawab. Ini sesuai dengan teori slack resource. Menurut Hoi, Wu, Zhang (2013) irresponsible CSR didominasi oleh perusahaan dengan kinerja laba rendah, sedangkan perusahaan dengan kinerja laba tinggi lebih berkomitmen dan memiliki program CSR jangka panjang, sehingga kecil kemungkinan melakukan penghindaran pajak. Hasil ini juga didukung Watson (2014) yang menemukan bahwa perusahaan dengan kualitas CSR yang baik tidak melakukan penghindaran pajak pada kondisi kinerja laba tinggi. Namun pada kondisi kinerja laba yang rendah, perusahaan terindikasi melakukan penghindaran pajak. Dari kedua penelitian tersebut dapat dijelaskan bahwa kinerja laba memperkuat pengaruh kualitas CSR terhadap penghindaran pajak. Berdasarkan penjelasan di atas, maka hipotesis penelitian ini adalah

$\mathrm{H}_{2}$ : Kinerja laba memperkuat pengaruh kualitas CSR terhadap penghindaran pajak

\section{METODE PENELITIAN}

\section{Model Analisis}

Penelitian ini menggunakan model Watson (2014) untuk membandingkan dengan kondisi di Indonesia. Perhitungan CETR dalam mengukur penghindaran pajak memiliki kelebihan yaitu memasukkan unsur permanent different dan temporary different. CETR diukur dengan jumlah pajak yang dibayar dibagi dengan laba sebelum pajak. Proksi kinerja laba yang digunakan dalam penelitian ini berbeda dengan yang digunakan Watson (2014). Penelitian ini menggunakan Return on Asset (ROA) dalam mengukur kinerja laba, sedangkan Watson menggunakan variable dummy. ROA diukur dengan membandingkan laba sebelum pajak dengan total asset t-1. Kualitas CSR diukur menggunakan variable dummy, kualitas diberi nilai 1 , bila perusahaan menerima CSR award, dan nilai 0 bila tidak menerima CSR award.

Penelitian ini menggunakan Moderated Regression Analysis (MRA) untuk menguji model berikut:

$\mathrm{CETR}_{i t}=$ $\beta_{0}+\beta_{1} \mathrm{CSR}_{i t}+\beta_{2}$ Kinerja_Laba $_{i t}+\beta_{3}$ CSR $_{i t} *$ Kinerja Laba $+\sum \beta_{4 . . . n}$ Controls $_{i t}+$ Year Fixed Effects ${ }_{i}+$ Industry Fixed Effects ${ }_{i t}+\varepsilon_{i t}$

Adapun variabel kontrol dalam penelitian ini adalah discretionary accrual, kepemilikan institusional, likuiditas, leverage, kompensasi kerugian, property plant equipment, aset tidak berwujud, laba afiliasi, penelitian dan pengembangan, jumlah karyawan, pertumbuhan penjualan, market value of equity, dan market to book ratio. Ukuran yang digunakan untuk variabel-variabel tersebut dapat dilihat pada lampiran 1 .

\section{Mengukur Kualitas CSR}

Penelitian ini menggunakan CSR award sebagai proksi kualitas CSR karena kriteria penilaian dari pemberian penghargaan ini dinilai memenuhi keempat unsur dari pengertian kualitas CSR, yaitu: (1) sesuai dengan kebutuhan masyarakat (original), (2) berkelanjutan (sustainable), (3) inovatif, dan (4) berdampak bagi masyarakat (high impact). Adapun CSR award yang digunakan adalah:

1. Global CSR Summit and Award yang diadakan oleh Pinnacle Group International

Memberikan penganugerahan kepada perusahaan dan lembaga nonprofit di Asia yang berprestasi dalam mengimplementasikan program CSR yang berdampak luas (high impact), original, sustainable, dan inovatif;

2. Indonesia CSR Award yang diadakan oleh lembaga non-profit Corporate Forum for Community Development (CFCD). Indonesia CSR Award CFCD dipilih karena telah memperoleh pengakuan dari HAKI Kementerian Hukum dan HAM RI.

Pengukuran kualitas CSR dinilai dari program CSR yang telah dilakukan perusahaan di tahun-tahun sebelumnya. Perusahaan yang menerima Global CSR Summit and Award, yang diadakan setiap tahun, diberikan skor 1 untuk tahun t-1. Bagi perusahaan yang menerima Indonesia CSR Award, yang diadakan tiga tahun sekali, diberikan skor 1 untuk tahun t-1, t-2 dan t-3.

\section{Penentuan Sampel}

Populasi dari penelitian ini adalah perusahaan yang terdaftar di Bursa Efek Indonesia pada tahun 2010-2014. Kriteria pemilihan sampel yang digunakan adalah:

1. Perusahaan tidak termasuk lembaga keuangan;

2. Perusahaan tidak termasuk jasa konstruksi dan properti yang perhitungan pajak penghasilannya berdasarkan penghasilan bruto, bukan laba bersih;

3. Perusahaan memiliki CETR dalam range 0-1 karena tarif pajak tidak boleh negatif atau lebih besar dari 1 (Guenther, 2014);

4. Perusahaan memiliki data lengkap menimal 3 tahun. 


\section{HASIL PENELITIAN DAN PEMBAHASAN}

\section{Gambaran Subjek Penelitian}

Objek dalam penelitian ini adalah perusahaan yang terdaftar di Bursa Efek Indonesia dari tahun 2010-2014 sebanyak 519 perusahaan. Penentuan sampel menggunakan purposive sampling, sehingga diperoleh 254 perusahaan yang memenuhi kriteria. Rangkuman penentuan sampel dapat dilihat pada tabel 1 .

Tabel 1. Populasi dan Sampel Penelitian

\begin{tabular}{lc}
\hline Kriteria Sampel & $\begin{array}{c}\text { Jumlah } \\
\text { perusahaan }\end{array}$ \\
\hline $\begin{array}{l}\text { Total Perusahaan yang terdaftar di BEI } \\
\text { tahun } 2010 \text { - 2014 }\end{array}$ & 519 \\
$\begin{array}{l}\text { Perusahaan yang bergerak dalam } \\
\text { sektor perbankan }\end{array}$ & $(72)$ \\
$\begin{array}{l}\text { Perusahaan yang bergerak dalam } \\
\text { sektor jasa konstruksi }\end{array}$ & $(8)$ \\
$\begin{array}{l}\text { Perusahaan yang bergerak dalam } \\
\text { sektor property dan real estate }\end{array}$ & $(39)$ \\
$\begin{array}{l}\text { Perusahaan yang baru terdaftar di BEI } \\
\text { tahun 2013 dan 2014 }\end{array}$ & $(68)$ \\
Perusahaan yang delisting & \\
$\begin{array}{l}\text { Perusahaan dengan data tidak lengkap } \\
\text { Sampel perusahaan berdasarkan } \\
\text { kriteria }\end{array}$ & $(1)$ \\
\hline
\end{tabular}

Jumlah perusahaan yang menjadi sampel penelitian adalah 254 perusahaan dengan observasi sebanyak 1136. Dilakukan reduksi data outlier sehingga jumlah sampel penelitian yang tersisa adalah 137 perusahaan dengan jumlah observasi sebanyak 615. Reduksi dilakukan untuk eliminasi data-data ekstrim yang dapat mengaburkan tujuan utama dari penelitian ini yaitu mem- buktikan bahwa perusahaan penerima CSR award tidak melakukan penghindaran pajak, dengan asumsi bahwa kondisi kinerja laba, keuangan, aset rata-rata perusahaan hampir sama.

\section{Deskripsi Statistik}

Tabel 2 menunjukkan statistik deskriptif 615 observasi data dari tahun 2010-2014. Variabel Kualitas CSR dan KompensasiRugi merupakan variabel dummy dengan nilai maksimum 1 dan minimum 0. Dari sisi jumlah karyawan, perusahaan yang diteliti rata-rata memiliki jumlah karyawan yang banyak, tetapi dari nilai standar deviasinya termasuk kecil, artinya selisih jumlah karyawan antar perusahaan cenderung tidak berbeda jauh. Variabel market value equity menunjukkan rata-rata yang rendah dibanding nilai mediannya. Begitu pula dengan standar deviasinya yang tergolong kecil.

Perusahaan yang diteliti memiliki rata-rata kinerja laba yang tinggi, jumlah discretionary accrual yang besar, persentase kepemilikan institusional tinggi, kas dari aktivitas operasi yang tinggi, leverage yang tinggi, perubahan nilai kompensasi kerugian yang besar, nilai property plant equipment yang besar, dan nilai pasar yang tinggi dibanding nilai buku perusahaan. Namun disisi lain standar deviasi dari variabel diatas juga termasuk tinggi, artinya varian data variabel tersebut cukup besar.

\section{Pembahasan Hasil Penelitian}

Penelitian ini menggunakan Moderated Regression Analysis (MRA) untuk melakukan

Tabel 2. Deskriptif Statistik

\begin{tabular}{lrrrrr}
\hline \multicolumn{1}{c}{ Variabel } & \multicolumn{1}{c}{ Mean } & \multicolumn{1}{c}{ Median } & Std. Deviation & \multicolumn{1}{c}{ Minimum } & \multicolumn{1}{c}{ Maximum } \\
\hline KinerjaLaba & .163220 & .124000 & .1785655 & -.2240 & 2.5360 \\
CETR & .233265 & .243000 & .1385176 & .0000 & .6580 \\
Abs_DAC & .392410 & .146000 & 1.0774726 & .0000 & 12.2280 \\
Institusional & .721350 & .700000 & 1.0272889 & .0000 & 25.6300 \\
Cash & .232927 & .108000 & 1.4299499 & .0000 & 35.1390 \\
Leverage & .217688 & .118000 & .3176484 & .0000 & 4.0730 \\
ChKompenRugi & .019943 & .000000 & .3929178 & -.4700 & 9.6600 \\
PPE & .408317 & .316000 & .4411217 & .0000 & 7.5520 \\
Intangible & .040145 & .000000 & .2543081 & .0000 & 5.2130 \\
LabaAfiliasi & .005013 & .000000 & .0255031 & -.0230 & .3970 \\
R\&D & .002839 & .000000 & .0231504 & .0000 & .2990 \\
Karyawan & 7.016763 & 6.927000 & 1.8083825 & .0000 & 11.9580 \\
Penjualan & .375704 & .143000 & 1.5964431 & -.8710 & 32.6010 \\
MVEquity & 18.582889 & 18.961000 & 3.4193075 & 9.3850 & 26.9540 \\
Market-to-book & 37.250498 & 6.727000 & 172.3962992 & .1110 & 2600.0000 \\
\hline
\end{tabular}


Tabel 3. Hasil Regresi

\begin{tabular}{|c|c|c|c|c|c|c|}
\hline \multicolumn{7}{|c|}{ Coefficients $^{\mathbf{a}}$} \\
\hline & \multirow[t]{2}{*}{ Model } & \multicolumn{2}{|c|}{ Unstandardized Coefficients } & \multirow{2}{*}{$\begin{array}{c}\begin{array}{c}\text { Standardized } \\
\text { Coefficients }\end{array} \\
\text { Beta } \\
\end{array}$} & \multirow[t]{2}{*}{$\mathrm{t}$} & \multirow[t]{2}{*}{ Sig. } \\
\hline & & $\mathrm{B}$ & Std. Error & & & \\
\hline \multirow[t]{22}{*}{$\overline{1}$} & (Constant) & .219 & .033 & & 6.623 & .000 \\
\hline & KualitasCSR & .227 & .064 & .284 & 3.562 & .000 \\
\hline & KinerjaLaba & -.069 & .032 & -.088 & -2.124 & .034 \\
\hline & KualitasCSR*KinerjaLaba & -1.135 & .293 & -.299 & -3.866 & .000 \\
\hline & Abs_DAC & .011 & .005 & .088 & 2.367 & .018 \\
\hline & Institusional & .016 & .005 & .115 & 3.116 & .002 \\
\hline & Cash & -.002 & .004 & -.023 & -.605 & .545 \\
\hline & Leverage & -.071 & .021 & -.163 & -3.387 & .001 \\
\hline & KompensasiRugi & -.042 & .015 & -.108 & -2.697 & .007 \\
\hline & ChangesKompenRugi & -.041 & .014 & -.115 & -2.830 & .005 \\
\hline & PPE & -.004 & .014 & -.012 & -.251 & .802 \\
\hline & Intangible & .063 & .021 & .115 & 2.937 & .003 \\
\hline & LabaAfiliasi & -.251 & .205 & -.046 & -1.221 & .222 \\
\hline & $\mathrm{R} \& \mathrm{D}$ & .175 & .520 & .029 & .337 & .737 \\
\hline & Karyawan & .023 & .003 & .305 & 6.956 & .000 \\
\hline & Penjualan & -.006 & .003 & -.067 & -1.717 & .087 \\
\hline & MVEquity & -.009 & .002 & -.218 & -4.005 & .000 \\
\hline & Market-to-book & $-1.994 \mathrm{E}-5$ & .000 & -.025 & -.280 & .780 \\
\hline & Tahun2011 & .039 & .020 & .112 & 1.897 & .058 \\
\hline & Tahun2012 & .033 & .020 & .099 & 1.631 & .103 \\
\hline & Tahun2013 & .048 & .021 & .141 & 2.319 & .021 \\
\hline & Tahun2014 & .053 & .021 & .150 & 2.560 & .011 \\
\hline
\end{tabular}

a. Dependent Variable: CETR

analisis pengaruh kualitas CSR terhadap penghindaran pajak. Obyek penelitian adalah perusahaan di Bursa Efek Indonesia (BEI) pada periode 2010-2014. Berikut ini adalah hasil analisis regresi terlihat pada Tabel 3.

Hasil pengujian pada Tabel 3 menunjukkan kualitas CSR berpengaruh negatif terhadap penghindaran pajak. Hal ini dapat dilihat dari nilai probabilitas $(0.000)>0.05$. Artinya sesuai hipotesis penelitian ini yaitu perusahaan dengan kualitas CSR yang baik, cenderung lebih sedikit melakukan penghindaran pajak. Ini ditunjukkan melalui CETR yang lebih tinggi dibanding perusahaan dengan kualitas CSR yang buruk. Alasannya adalah perusahaan dengan kualitas CSR yang baik adalah perusahaan yang memiliki sumber daya melimpah, sehingga dapat menjalankan aktivitas CSR secara berkelanjutan sekaligus membayar pajak dengan mudah. Pendapat ini didukung teori slack resource (Campbell, 2007) yang menyatakan dalam kondisi sumber daya terbatas, perusahaan akan melakukan alokasi antara aktivitas CSR dan pajak, tetapi ini tidak terjadi dalam kondisi yang sebaliknya. Penelitian Lys, Naughton, dan Wang (2013) menyatakan bahwa kualitas CSR yang baik merupakan sinyal perusahaan tersebut kaya, sehingga membayar pajak lebih tinggi. Tabel 5 Perbandingan sumber daya yang dimiliki dilihat dari total asset, rasio Property Plant dan Equip- ment, rasio market value of equity antara perusahaan dengan kualitas CSR yang baik dibanding perusahaan dengan kualitas CSR yang buruk. Dalam Tabel 4 terlihat dalam ketiga aspek, perusahaan dengan kualitas CSR yang baik memiliki sumber daya yang lebih besar.

Tabel 4. Perbandingan Sumber Daya yang Dimiliki

\begin{tabular}{lcc}
\hline \multicolumn{1}{c}{$\begin{array}{c}\text { Item yang } \\
\text { dibandingkan }\end{array}$} & $\begin{array}{c}\text { Perusahaan } \\
\text { Kualitas CSR =1 }\end{array}$ & $\begin{array}{c}\text { Perusahaan } \\
\text { Kualitas CSR =0 }\end{array}$ \\
\hline $\begin{array}{l}\text { Rata-rata total aset } \\
\text { per tahun }\end{array}$ & $69,819,572$ & $4,279,516$ \\
$\begin{array}{l}\text { Rata-rata rasio } \\
\text { Property Plant dan } \\
\text { Equipment per }\end{array}$ & 0.60 & 0.40 \\
tahun & & \\
$\begin{array}{l}\text { Rata-rata Rasio } \\
\text { Market Value of } \\
\text { Equity per tahun }\end{array}$ & 22.56 & 18.46 \\
\hline
\end{tabular}

Perusahaan dengan kualitas CSR yang baik adalah perusahaan yang sukarela dalam melakukan aktivitas CSR, artinya perusahaan tersebut tidak termasuk dalam daftar perusahaan yang wajib CSR menurut Undang-Undang No 40 Tahun 2007. Perusahaan yang diwajibkan melaksanakan aktivitas CSR adalah perusahaan yang bergerak dalam bidang sumber daya alam, seperti: pertambangan dan perkebunan. Pendapat ini didukung Friedman (1970) menyatakan tanggung 
jawab sosial tidak akan terjadi jika tidak ada pemahaman yang sama (kebulatan suara) antara perusahaan, pemerintah, dan masyarakat. Tanggung jawab sosial tidak akan terjadi bila tidak ada perikatan secara sukarela di dalamnya. Tabel 5 menunjukkan perusahaan dengan kualitas CSR yang baik merupakan perusahaan yang secara sukarela melakukan aktivitas CSR dan didominasi oleh sektor industri non-natural resources.

Tabel 5. Sektor Industri Perusahaan dengan Kualitas CSR yang Baik

\begin{tabular}{lc}
\hline \multicolumn{1}{c}{ Sektor Industri } & Jumlah Perusahaan \\
\hline Aneka Industri & 1 \\
Infrastruktur, Utilitas, & \\
Transportasi & 3 \\
Industri Dasar dan Kimia & 3 \\
\hline
\end{tabular}

Perusahaan dengan kualitas CSR tinggi, memandang pembayaran pajak sebagai bagian dari tanggung jawab sosial. Perusahaan tidak beranggapan bahwa pembayaran pajak dan CSR sebagai sesuatu yang dapat dipertukarkan (substitute). Dalam pedoman laporan berkelanjutan GRI, pembayaran pajak merupakan salah satu bagian dari CSR. Christensen and Murphy (2004), Avi-Yonah (2008), Devinney (2009), Lanis dan Richardson (2012), Preuss (2010), dan Sikka (2011) serta ketentuan perpajakan di beberapa negara seperti Australia mendukung perspektif di mana pembayaran pajak adalah tanggung jawab sosial utama perusahaan. Didukung dengan hasil penelitian Zu dan Song (2009) yang melakukan survei mengenai persepsi manajer di China terhadap tindakan yang bertanggung jawab sosial dan dari survei tersebut dapat disimpulkan bahwa manajer setuju bahwa kepatuhan terhadap peraturan pemerintah dan menjadi pembayar pajak yang baik adalah tindakan yang bertanggung jawab sosial dengan hasil survei sebanyak $72,3 \%$. Hasil penelitian ini didukung oleh penelitian $\mathrm{Hoi}$, $\mathrm{Wu}$, dan Zhang (2013) yang menemukan bahwa perusahaan dengan banyak aktivitas CSR yang tidak bertanggung jawab (irresponsible CSR), lebih besar kemungkinan melakukan penghindaran pajak. Penelitian Lanis dan Richardson (2015) menemukan bahwa perusahaan yang lebih bertanggung jawab sosial kemungkinan kecil melakukan penghindaran pajak. Penelitian Christensen dan Murphy (2004) juga mengemukakan bahwa perusahaan yang bertanggung jawab sosial membayar pajak dalam jumlah yang wajar. Tabel 6 menunjukkan perusahaan dengan kualitas CSR yang baik membayar pajak lebih tinggi dibanding kualitas CSR yang buruk.

Perusahaan dengan kualitas CSR yang baik rata-rata memiliki kinerja laba yang lebih tinggi dibanding perusahaan lain, sehingga membayar pajak lebih tinggi. Ini disebabkan dalam sampel perusahaan yang diteliti, dasar pengenaan pajak atas pajak penghasilan seluruh perusahaan di Indonesia adalah laba bersih. Tabel 7 menunjukkan rata-rata kinerja laba perusahaan dengan kualitas CSR yang baik, lebih tinggi dibanding kualitas CSR yang buruk.

Tabel 6. Perbandingan Cash Effective Tax Ratio (CETR)

\begin{tabular}{lcc}
\hline \multicolumn{1}{c}{$\begin{array}{c}\text { Item yang } \\
\text { dibandingkan }\end{array}$} & $\begin{array}{c}\text { Perusahaan } \\
\text { Kualitas CSR =1 }\end{array}$ & $\begin{array}{c}\text { Perusahaan } \\
\text { Kualitas CSR }=0\end{array}$ \\
\hline $\begin{array}{l}\text { Cash Effective Tax } \\
\text { Ratio (CETR) per } \\
\text { tahun }\end{array}$ & 0.24 & 0.23 \\
\hline
\end{tabular}

Tabel 7. Perbandingan Kinerja Laba per Tahun

\begin{tabular}{lcc}
\hline \multicolumn{1}{c}{$\begin{array}{c}\text { Item yang } \\
\text { dibandingkan }\end{array}$} & $\begin{array}{c}\text { Perusahaan } \\
\text { Kualitas CSR }=1\end{array}$ & $\begin{array}{c}\text { Perusahaan } \\
\text { Kualitas CSR }=0\end{array}$ \\
\hline $\begin{array}{l}\text { Kinerja Laba per } \\
\text { tahun }\end{array}$ & 0.18 & 0.16 \\
\hline
\end{tabular}

Perusahaan penerima CSR award telah memiliki program CSR yang berkelanjutan, sehingga pelaksanaan program CSR setiap tahun tidak dipengaruhi besarnya pajak yang dibayar pada tahun tersebut. Hal ini dapat dilihat dari meningkatnya jumlah perusahaan yang membuat laporan sustainability selama 10 tahun terakhir. Menurut Darwin (2013), Ketua National Corporate Sustainability Reporting, yang dikutip dari swa. co.id, jumlah perusahaan yang membuat laporan sustainability semakin banyak. Jika pada tahun 2005, hanya 6-10 perusahaan, maka pada tahun 2013 jumlahnya telah mencapai 40 perusahaan yang telah membuat laporan berkelanjutan dengan mengacu pada the Global Reporting Initiative (GRI).

Hasil pengujian menunjukkan kinerja laba secara independen berpengaruh positif terhadap penghindaran pajak. Hal ini ditunjukkan dari nilai probabilitas $(0.034)<0.05$ dimana berarti semakin tinggi kinerja laba, semakin tinggi penghindaran pajak yang dilakukan. Analisis ini ditunjukkan dari CETR yang semakin kecil. Penjelasannya adalah dasar pengenaan pajak $\mathrm{PPh}$ badan adalah laba bersih, sehingga semakin tinggi laba bersih, maka semakin tinggi pajak yang harus dibayar. Untuk menghindari hal tersebut, perusahaan melakukan tindakan penghindaran pajak pada periode dimana kinerja laba tinggi, sehingga menyebabkan CETR menjadi rendah. Hasil penelitian ini menemukan bahwa perusahaan dengan kinerja laba yang tinggi cenderung melakukan penghindaran pajak. Penjelasannya adalah kinerja laba yang tinggi menyebabkan perusahaan harus membayar pajak dalam jumlah 
yang lebih besar. Di Indonesia angsuran $\mathrm{PPh}$ badan diangsur dimuka, yaitu pada awal tahun pajak, menggunakan dasar penghasilan tahun sebelumnya. Kinerja laba yang tinggi pada suatu perusahaan memicu manajemen untuk melakukan penghindaran pajak, terutama pada kondisi dimana manajemen tidak terlalu optimis terhadap kinerja di tahun berikutnya. Kinerja laba yang tinggi pada tahun tertentu yang dilanjutkan penurunan laba pada tahun berikutnya, menyebabkan perusahaan mengalami kelebihan pembayaran pajak. Restitusi atas kelebihan pajak harus melalui pemeriksaan pajak. Menurut UU No 27 Tahun 2007 hasil pemeriksaan pajak yaitu Surat Ketetapan Pajak Lebih Bayar (SKPLB) diterbitkan paling lama 12 bulan sejak berkas permohonan diterima lengkap. Prosedur restitusi yang panjang dan lama membuat perusahaan cenderung melakukan penghindaran pajak pada saat kinerja laba tinggi. Selain alasan tersebut, biaya konsultan pajak untuk mengurus restitusi dan pemeriksaan pajak cukup besar.

Hasil pengujian terhadap pengaruh kualitas CSR terhadap penghindaran pajak dengan kinerja laba sebagai moderator menemukan bahwa interaksi kinerja laba dengan kualitas CSR memperkuat negatif pengaruh kualitas CSR terhadap penghindaran pajak. Artinya perusahaan dengan kualitas CSR yang baik dan kinerja laba yang tinggi, cenderung melakukan penghindaran pajak. Hal ini dapat dilihat dari nilai probabilitas (0.000) $>0.05$. Nilai standardized beta (absolut) kualitas CSR sebesar 0,284 dan nilai beta Kualitas CSR* KinerjaLaba sebesar 0,299 menunjukkan kenaikan dari 0,284 menjadi 0,299, namun unstandardized beta menunjukkan arah yang negatif. Ini berarti perusahaan dengan kualitas CSR yang baik dan memiliki kinerja laba tinggi, cenderung melakukan penghindaran pajak. Tabel 8 menunjukkan pengaruh kualitas CSR terhadap penghindaran pajak, baik secara independen maupun dimoderasi oleh kinerja laba sebagai moderator.

Tabel 8. Hasil Regresi Kualitas CSR dan Kualitas CSR Dimoderasi Kinerja Laba

\begin{tabular}{lccc}
\hline \multicolumn{1}{c}{ Model } & $\begin{array}{c}\text { Unstandardized } \\
\text { Coefficients } \\
\text { B }\end{array}$ & $\begin{array}{c}\text { Standardized } \\
\text { Coefficients } \\
\text { Beta }\end{array}$ & Sig. \\
\hline $\begin{array}{l}\text { KualitasCSR } \\
\text { Kualitas CSR }\end{array}$ & 0.227 & 0.284 & 0.0000 \\
Kinerja Laba & -1.135 & -0.299 & 0.0000 \\
\hline
\end{tabular}

Hasil ini berkebalikan dengan penelitian Watson (2014) yang menyatakan bahwa perusahaan dengan kualitas CSR yang baik melakukan penghindaran pajak hanya pada kondisi kinerja laba yang rendah. Bila dilihat dari pengujian pengaruh kinerja laba (secara independen) terhadap penghindaran pajak diatas, hal ini dapat dijelaskan karena seluruh perusahaan sampel penelitian ini cenderung melakukan penghindaran pajak saat kondisi kinerja laba tinggi, tanpa membedakan apakah kualitas CSR baik atau buruk. Alasan yang pertama sama dengan yang telah diungkapkan sebelumnya bahwa kinerja laba yang tinggi menyebabkan terjadi kelebihan pembayaran pajak pada tahun-tahun berikutnya, sehingga perusahaan harus melakukan restitusi pajak dan menjalani pemeriksaan pajak yang membutuhkan waktu yang lama di Indonesia (12 bulan). Mengapa penelitian Watson (2014) di USA berbeda dengan hasil penelitian ini di Indonesia? Ada beberapa perbedaan mendasar dalam mekanisme restitusi di Indonesia dan USA, antara lain di USA restitusi pajak membutuhkan waktu sekitar 3 minggu bila pengajuan lewat pos dan waktu yang lebih pendek bila diajukan melalui internet. Penelitian ini juga menemukan bahwa discretionary accrual, kepemilikan institusional, intangible asset, jumlah karyawan berpengaruh negatif terhadap penghindaran pajak.

\section{KESIMPULAN DAN SARAN}

Hasil penelitian menunjukkan kualitas CSR berpengaruh negatif terhadap penghindaran pajak. Perusahaan dengan kualitas CSR yang baik cenderung mengalami penurunan penghindaran pajak. Namun perusahaan dengan kualitas CSR yang baik saat dimoderasi dengan kinerja laba yang tinggi, hasilnya menunjukkan perusahaan cenderung mengalami peningkatan penghindaran pajak. Hal ini karena kinerja laba yang tinggi menyebabkan terjadi kelebihan pembayaran pajak pada tahun-tahun berikutnya, sehingga perusahaan harus melakukan restitusi pajak dan menjalani pemeriksaan pajak yang membutuhkan waktu yang lama di Indonesia (12 bulan). Dalam hal ini perusahaan menghindari kelebihan pembayaran pajak dengan cara melakukan penghindaran pajak pada kondisi kinerja laba tinggi. Hasil ini konsisten dengan pengujian pengaruh kinerja laba secara independen terhadap penghindaran pajak, dimana ditemukan pengaruh positif atas hubungan keduanya.

Selain itu penelitian ini juga menemukan discretionary accrual, kepemilikan institusional, intangible asset, jumlah karyawan berpengaruh negatif terhadap penghindaran pajak. Hal yang paling menarik untuk diteliti lebih lanjut dimana tahun 2013 dan 2014 merupakan tahun dimana penghindaran pajak lebih rendah dibanding tahuntahun sebelumnya. Ini membuktikan bahwa program penegakan hukum di Indonesia khususnya 
dalam bidang perpajakan 2 tahun terakhir berhasil menaikkan Cash Effective Tax Ratio (CETR) korporasi.

\section{DAFTAR PUSTAKA}

Agnes Cheng, C.S., Huang, H.H., Li, Y., \& Stanfield, J. (2012). The effect of hedge fund activism on corporate tax avoidance. The Accounting Review, 87(5), 1493-1526. http://doi.org/ 10.2308/accr-50195

Avi-Yonah, R.S. (2008). Corporate Social Responsibility and Strategic tax Behaviour. In Tax and Corporate Governance (pp. 183-198). http://doi.org/10.1007/978-3-540-77276-7

Campbell, J.L. (2007) 'Why Would Corporations Behave in Socially Responsible Ways? An Institutional Theory of Corporate Social Responsibility', Academy of Management Review, 32, 946-967.

Christensen, John \& Murphy, Richard (2004). The Social Irresponsibility of Corporate Tax Avoidance: Taking CSR to the bottom line. Society for International Development, 37-44

Davis, A.K., Guenther, D.G., Krull, L.K., \& Williams, B.M. (2013). Taxes and Corporate Sustainability Reporting: Is Paying Taxes Viewed as Socially Responsible? Available at SSRN .... Retrieved from http://papers.ssrn. com/sol3/papers.cfm?abstract_id=2275633

Devinney, Timothy, (2009). Is the Socially Responsible Corporation a Myth? The Good, the Bad, and the Ugly of Corporate Social Responsibility. Academy of Management Perspectives, May (44)

Dyreng, S.D., Hanlon, M., \& Maydew, E.L. (2010). The effects of executives on corporate tax avoidance. Accounting Review, 85(4), 11631189. ttp://doi.org/10.2308/accr.2010.85.4.1163

Friedman, M. (1970). The social responsibility of business is to increase its profits. The New York Times Magazine (September 13).

Guenther, D.A. (2014). Measuring corporate tax avoidance: Effective tax rates and book-tax differences, (541), 1-24.

Gunawan, Juniati. 2009. Mengukur Kinerja Tanggung Jawab Sosial Perusahaan. http://www. ncsr-id.org/2009/09/02/mengukur-kinerjatanggung-jawab-sosial-perusahaan/

Hoi, C.K., Wu, Q., \& Zhang, H. (2013). Is corporate social responsibility (CSR) associated with tax avoidance? Evidence from irresponsible CSR activities. The Accounting Review, 88(6), 2025-2059. http://doi.org/10.2308/accr-50544

Khurana, I.K., \& Moser, W.J. (2009). Institutional Ownership and Tax Aggressiveness. SSRN Electronic Journal. http://doi.org/10.2139/ssrn. 1464106

Klinger, S., Anderson, S., Collins, C., Cavanagh, J., \& Pizzigati, S. (2011, October 3). America loses: Corporations that take tax holidays slash jobs. The Institute for Policy Studies. Washington, $D C$

Koestoer, Y. 2014. Corporate Social Responsibility In Developing Countries. http://www.developmentinstitute.org/wp-content/uploads/2015/ 05/koestoer_script.pdf

Lanis, R., \& Richardson, G. (2012). Corporate social responsibility and tax aggressiveness: An empirical analysis. Journal of Accounting and Public Policy, 31(1), 86-108. http://doi.org/ 10.1016/j.jaccpubpol.2011.10.006

Lietz, Gerrit M., Tax Avoidance vs. Tax Aggressiveness: A Unifying Conceptual Framework (2013). Available at SSRN: https://ssrn.com/ abstract=2363828 or http://dx.doi.org/10.2139/ ssrn.2363828

Lys, T., Naughton, J.P., \& Wang, C. (2015). Signaling Through Corporate Accountability Reporting. Journal of Accounting and Economics (60), 56-72.

Preuss, L. (2010). Tax Avoidance and Corporate Social Responsibility: You Can't Do Both or Can You? Corporate Governance, 10 (4), 365374

Suharto, E. (2008). Menggagas Standar Audit Program CSR. http://www.policy.hu/suharto/ Naskah\%20PDF/CSRAudit.pdf

Republik Indonesia. 2007. Undang-Undang Nomor 40 Tahun 2007 tentang Perseroan Terbatas. Kementrian Hukum dan HAM

Republik Indonesia. 2008. Undang Undang No 36 Tahun 2008 tentang Pajak Penghasilan. Sekretariat Negara.

Watson, L. (2014). Corporate Social Responsibility, Tax Avoidance, and Earnings Performance. Journal of the American Taxation Association 37 (2): 1-21

Zu, L., \& Song, L. (2009). Determinants of Managerial Values on Corporate Social Responsibility: Evidence from China. Journal of Business Ethics (88), 105-117. 


\section{Lampiran 1. Indikator Variabel}

\begin{tabular}{|c|c|c|}
\hline Variabel & Indikator & Skala \\
\hline \multirow{2}{*}{$\begin{array}{l}\text { Cash Effective Tax } \\
\text { Ratio (CETR) }\end{array}$} & \multirow{2}{*}{$C E T R=\frac{\text { Cash taxes paid }}{\text { Pretax income }}$} & \multirow[t]{2}{*}{ Ratio } \\
\hline & & \\
\hline Kualitas CSR (QCSR) & $\begin{array}{l}\text { CSR = } 1 \text { pada tahun t-1, jika perusahaan memperoleh CSR award dari Global CSR } \\
\text { Summit Award (tahunan) } \\
\text { CSR = } 1 \text { pada tahun t-1, t-2, t- } 3, \text {,jika perusahaan memperoleh CSR award dari } \\
\text { Indonesia CSR Award (setiap tiga tahunan) } \\
\text { CSR = 0, jika perusahaan tidak memperoleh CSR award }\end{array}$ & Nominal \\
\hline \multirow[t]{2}{*}{ Kinerja Laba (ROA) } & \multirow{2}{*}{$R O A=\frac{\text { Pretaxincome }}{\text { Totalasset } s_{t-1}}$} & \multirow[t]{2}{*}{ Ratio } \\
\hline & & \\
\hline \multirow{3}{*}{$\begin{array}{l}\text { Kepemilikan } \\
\text { Institusional (INST) } \\
\text { Likuiditas (Cash) }\end{array}$} & Persentase kepemilikan institusi & Ratio \\
\hline & \multirow{2}{*}{ Cash $=\frac{\text { Kas dan Setara kas }}{\text { Total Aset } t-1}$} & \multirow[t]{2}{*}{ Ratio } \\
\hline & & \\
\hline \multirow[t]{2}{*}{ Leverage } & \multirow{2}{*}{ Lev $=\frac{\text { Total long term debt }}{\text { Total asset } s_{t-1}}$} & \multirow[t]{2}{*}{ Ratio } \\
\hline & & \\
\hline \multirow{3}{*}{$\begin{array}{l}\text { Kompensasi Pajak atas } \\
\text { Kerugian (Kompensasi } \\
\text { Rugi) } \\
\text { Selisih Kompensasi } \\
\text { Kerugian tahun t dan } \\
\text { t-1 (ChKompenRugi) } \\
\end{array}$} & $\begin{array}{l}\text { TaxLoss }=1, \text { if the company has tax loss compensation for year } \mathrm{t} \\
\text { TaxLoss }=0, \text { if the company doesn't has tax loss compensation for year } \mathrm{t}\end{array}$ & Nominal \\
\hline & \multirow{2}{*}{ Ch Kompen Rugi $=\frac{\left(\text { Kompensasi Rugi }{ }_{t}+\text { Kompensasi Rugi }_{t-1}\right.}{\text { Kompensasi Rugi }{ }_{t-1}}$} & \multirow[t]{2}{*}{ Ratio } \\
\hline & & \\
\hline \multirow{2}{*}{$\begin{array}{l}\text { Property, Plant and } \\
\text { Equipment (PPE) }\end{array}$} & \multirow{2}{*}{$P P E=\frac{\text { fixed assets }}{\text { Total asset } s_{t-1}}$} & \multirow[t]{2}{*}{ Ratio } \\
\hline & & \\
\hline \multirow[t]{2}{*}{ Intangible Asset } & \multirow{2}{*}{ INTAN $=\frac{\text { Intangible assets }}{\text { Total asset } s_{t-1}}$} & \multirow[t]{2}{*}{ Ratio } \\
\hline & & \\
\hline \multirow[t]{2}{*}{ Laba Afiliasi } & \multirow{2}{*}{ Laba Afiliasi $=\frac{\text { Laba Afiliasi }}{\text { Totalaset } t-1}$} & \multirow[t]{2}{*}{ Ratio } \\
\hline & & \\
\hline \multirow{2}{*}{$\begin{array}{l}\text { Research \& } \\
\text { Development (R\&D) }\end{array}$} & \multirow{2}{*}{$R \& D=\frac{\text { Research and developmen t expense }}{\text { Totalasset } s_{t-1}}$} & \multirow[t]{2}{*}{ Ratio } \\
\hline & & \\
\hline Jumlah Karyawan & Karyawan $=\ln$ (jumlah karyawan) & Ratio \\
\hline Penjualan (Sales) & Penjualan $=\frac{\text { Penjualan }_{1}-\text { Penjualan }_{t-1}}{\text { Penjualant }-1}$ & Ratio \\
\hline $\begin{array}{l}\text { Market value of equity } \\
\text { (MVEquity) }\end{array}$ & MVEquity = ln (jumlah saham beredar X harga penutupan saham) & Ratio \\
\hline Market to book & jumlah saham beredar $x$ harga pasar saat penutupan sahan akhir tahun & Ratio \\
\hline & nilai buku & \\
\hline
\end{tabular}




\section{Lampiran 2. Hasil Uji Asumsi Klasik}

Uji Normalitas

One-Sample Kolmogorov-Smirnov Test

\begin{tabular}{llr}
\hline & & $\begin{array}{c}\text { Unstandardized } \\
\text { Residual }\end{array}$ \\
\hline $\mathrm{N}$ & Mean & 615 \\
Normal Parameters &, 0000000 \\
& Std. Deviation &, 12475565 \\
& Absolute &, 035 \\
Most Extreme Differences & Positive &, 035 \\
& Negative &,- 030 \\
Kolmogorov-Smirnov Z & &, 858 \\
Asymp. Sig. (2-tailed) & &, 453 \\
\hline
\end{tabular}

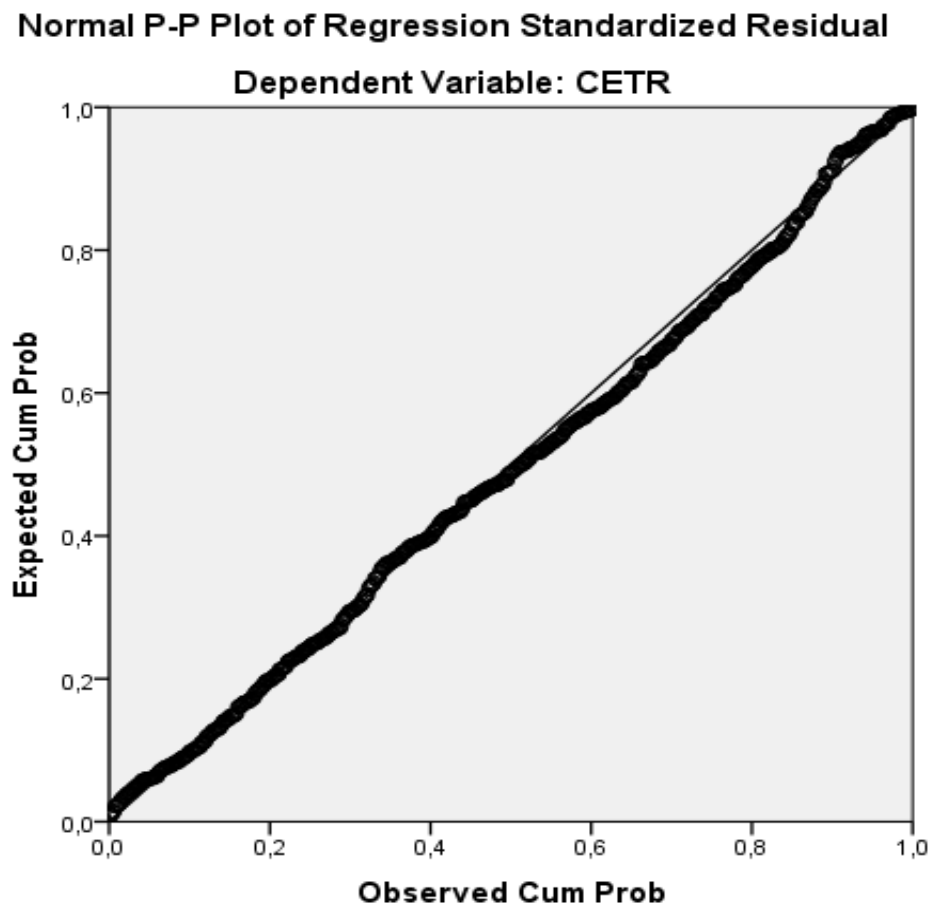

Uji Multikolinieritas

\begin{tabular}{lcc}
\hline \multicolumn{1}{c}{ Variabel } & Tolerance & VIF \\
\hline CSR & 0,214 & 4,672 \\
HIPROFIT & 0,784 & 1,275 \\
CSR*HIPROFIT & 0,227 & 4,407 \\
Abs DAC & 0,971 & 1,030 \\
IO & 0,995 & 1,005 \\
CASH & 0,962 & 1,040 \\
LEV & 0,584 & 1,712 \\
NOL & 0,858 & 1,165 \\
CHANGES NOL & 0,821 & 1,218 \\
PPE & 0,638 & 1,567 \\
INTAN & 0,885 & 1,129 \\
EQINC & 0,959 & 1,043 \\
RD & 0,179 & 5,571 \\
EMP & 0,765 & 1,306 \\
SALES & 0,882 & 1,133 \\
MVEQ & 0,815 & 1,226 \\
MB & 0,172 & 5,811 \\
\hline
\end{tabular}


Uji Heterokedastisitas

Scatterplot

Dependent Variable: CETR

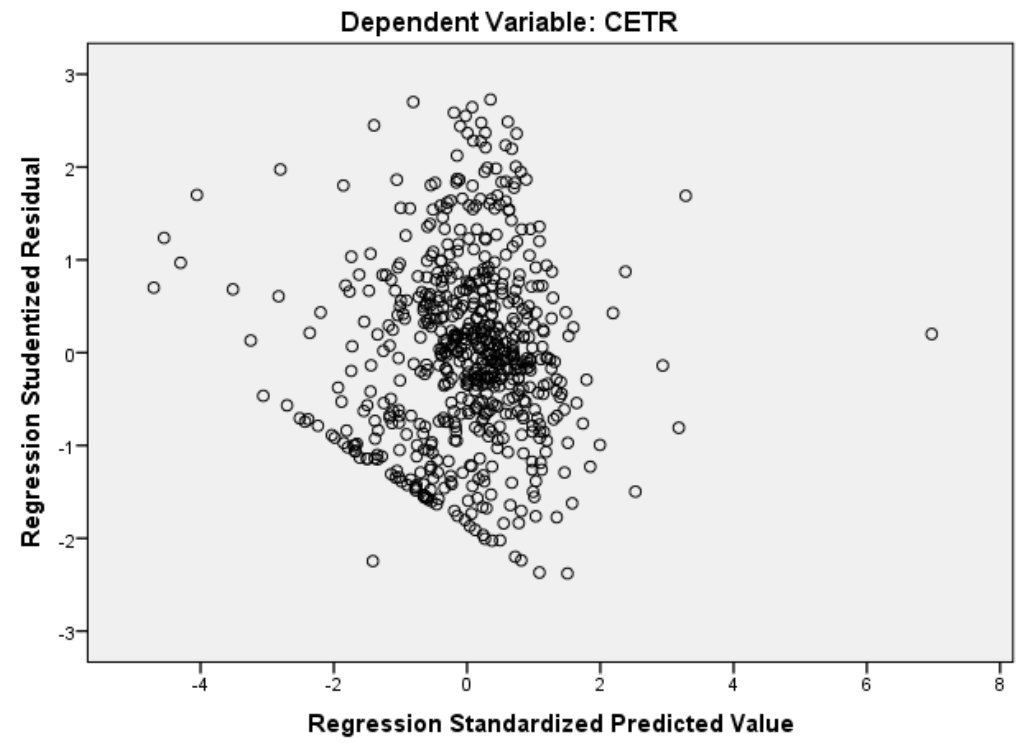

Uji Autokorelasi

Model Summary ${ }^{b}$

\begin{tabular}{cccccc}
\hline Model & $\mathrm{R}$ & R Square & $\begin{array}{c}\text { Adjusted R } \\
\text { Square }\end{array}$ & $\begin{array}{c}\text { Std. Error of the } \\
\text { Estimate }\end{array}$ & Durbin-Watson \\
\hline 1 & $.446^{\mathrm{a}}$ & .199 & .171 & .1261522 & 1.331 \\
\hline
\end{tabular}


Lampiran 3. Hasil Uji Moderated Regression Analysis (MRA)

Model Summary

\begin{tabular}{ccccc}
\hline Model & $\mathrm{R}$ & R Square & $\begin{array}{c}\text { Adjusted R } \\
\text { Square }\end{array}$ & $\begin{array}{c}\text { Std. Error of } \\
\text { the Estimate }\end{array}$ \\
\hline 1 & $.446^{\mathrm{a}}$ & .199 & .171 & .1261522 \\
\hline
\end{tabular}

\begin{tabular}{llrrrrr}
\multicolumn{7}{c}{ ANOVA $^{\mathbf{b}}$} \\
\hline Model & & Sum of Squares & \multicolumn{1}{c}{ df } & Mean Square & F & Sig. \\
\hline 1 & Regression & 2.344 & 21 & .112 & 7.013 & $.000^{\mathbf{a}}$ \\
& Residual & 9.437 & 593 & .016 & & \\
& Total & 11.781 & 614 & & & \\
\hline
\end{tabular}

Coefficients $^{\mathbf{a}}$

\begin{tabular}{|c|c|c|c|c|c|c|}
\hline & \multirow{2}{*}{ Model } & \multicolumn{2}{|c|}{ Unstandardized Coefficients } & \multirow{2}{*}{$\begin{array}{c}\begin{array}{c}\text { Standardized } \\
\text { Coefficients }\end{array} \\
\text { Beta } \\
\end{array}$} & \multirow[t]{2}{*}{$\mathrm{t}$} & \multirow[t]{2}{*}{ Sig. } \\
\hline & & $\mathrm{B}$ & Std. Error & & & \\
\hline \multirow[t]{22}{*}{1} & (Constant) & .219 & .033 & & 6.623 & .000 \\
\hline & KualitasCSR & .227 & .064 & .284 & 3.562 & .000 \\
\hline & KinerjaLaba & -.069 & .032 & -.088 & -2.124 & .034 \\
\hline & KualitasCSR*KinerjaLaba & -1.135 & .293 & -.299 & -3.866 & .000 \\
\hline & Abs_DAC & .011 & .005 & .088 & 2.367 & .018 \\
\hline & Institusional & .016 & .005 & .115 & 3.116 & .002 \\
\hline & Cash & -.002 & .004 & -.023 & -.605 & .545 \\
\hline & Leverage & -.071 & .021 & -.163 & -3.387 & .001 \\
\hline & KompensasiRugi & -.042 & .015 & -.108 & -2.697 & .007 \\
\hline & ChangesKompenRugi & -.041 & .014 & -.115 & -2.830 & .005 \\
\hline & PPE & -.004 & .014 & -.012 & -.251 & .802 \\
\hline & Intangible & .063 & .021 & .115 & 2.937 & .003 \\
\hline & LabaAfiliasi & -.251 & .205 & -.046 & -1.221 & .222 \\
\hline & $\mathrm{R} \& \mathrm{D}$ & .175 & .520 & .029 & .337 & .737 \\
\hline & Karyawan & .023 & .003 & .305 & 6.956 & .000 \\
\hline & Penjualan & -.006 & .003 & -.067 & -1.717 & .087 \\
\hline & MVEquity & -.009 & .002 & -.218 & -4.005 & .000 \\
\hline & Market-to-book & $-1.994 \mathrm{E}-5$ & .000 & -.025 & -.280 & .780 \\
\hline & Tahun2011 & .039 & .020 & .112 & 1.897 & .058 \\
\hline & Tahun2012 & .033 & .020 & .099 & 1.631 & .103 \\
\hline & Tahun2013 & .048 & .021 & .141 & 2.319 & .021 \\
\hline & Tahun2014 & .053 & .021 & .150 & 2.560 & .011 \\
\hline
\end{tabular}

a. Dependent Variable: CETR 